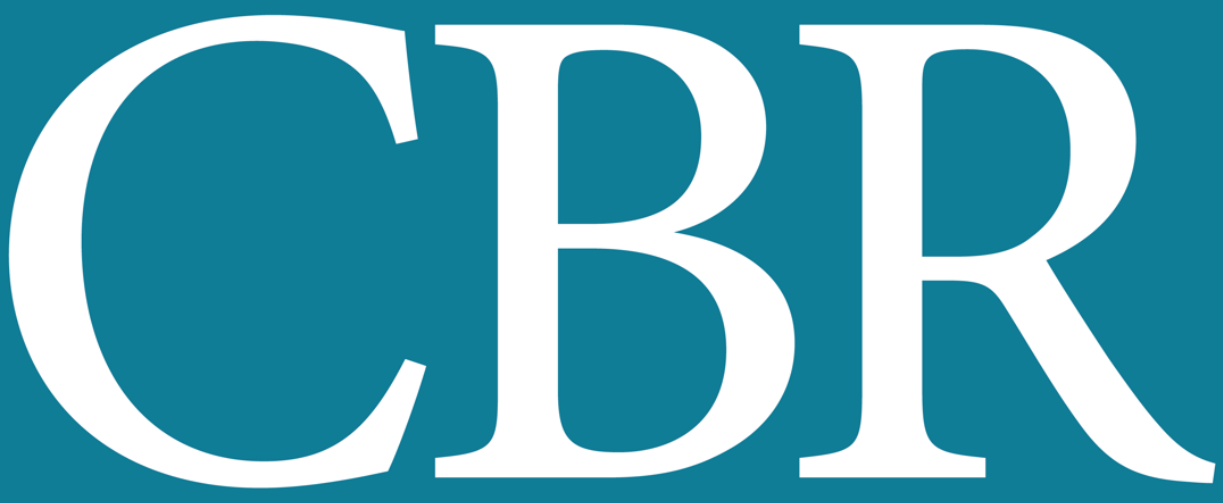

INTERNATIONAL JOURNAL OF CANCER AND BIOMEDICAL RESEARCH

https://jcbr.journals.ekb.eg

Editor-in-chief

Prof. Mohamed Labib Salem, PhD

In vivo and in vitro antitumor effects of Helix desertorumhemolymph by inducing cell cycle arrest and apoptosis

Mai A. Ziada, Mohamed H. Mona, Mohamed Basyony and Mohamed L. Salem 


\section{Welcome letter from Editor-in-Chief}

Welcome to the Int J Cancer and Biomedical Research (IJCBR)!

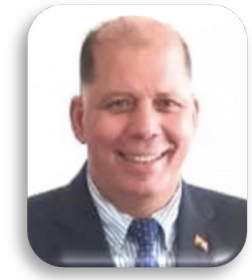

It is with great pleasure that I write this editorial to welcome you to the IJCBR. This journal provides a platform for publication of original and reviews research articles, short communications, letter to editor, thesis abstract, conference report, and case studies. These types of publication are directed at the interface of the fields of cancer and biomedical research.

The IJCBR relies on a distinguished expert of the Advisory and Editorial Board Members from the top international league covering in depth the related topics. They timely review all manuscripts and maintain highest standards of quality and scientific methodology and ethical concepts. Meanwhile, we take all possible means to keep the time of the publication process as short as possible.

I take this chance to welcome your contributions to the IJCBR and have every expectation that it will soon become one of the most respected journals in both the fields of cancer and biomedical research.

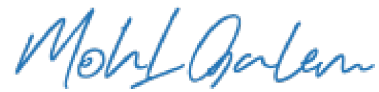

Mohamed L. Salem,

Editor in Chief 


\title{
In vivo and in vitro antitumor effects of Helix desertorum hemolymph by inducing cell cycle arrest and apoptosis
}

\author{
Mai A. Ziada, Mohamed H. Mona, Mohamed Basyony and Mohamed L. Salem
}

Zoology Department, Faculty of Science, Tanta University, Tanta, Egypt

\section{ABSTRACT}

Background: Natural products, those extracted from invertebrate animals have medical importance as therapeutic agents especially for cancer treatment. Aim of the Work: The current study was conducted to evaluate the antitumor effect of the hemolymph of the desert snail, Helix desertorum (HD-H) on tumor Ehrlich ascetic carcinoma cells (EAC) cell line in vitro and in vivo. Materials and Methods: Helix desertorum (HD-H) was collected from their suitable habitats, identified, and then their hemolymph was collected, to evaluate their antitumor effect. 40 female albino mice were divided into five groups $(n=8)$ as the following: group 1 (Gp1) control mice were inoculated intraperitoneal (i.p) with 1×106 EAC cells/mouseat day 0, Gp2 (EAC/Cis): Mice were injected with EAC-cells as in $\mathrm{Gp} 1$ and at day 2 were injected with cisplatin $(40 \mathrm{mg} / \mathrm{Kg}), \mathrm{Gp} 3$ was inoculated with EAC and then treated with splenocytes activated with $\mathrm{HD}-\mathrm{H}, \mathrm{Gp} 4$ was inoculated with EAC and then treated with splenocytes activated with IL-2/Con A, and Gp5 was inoculated with EAC and then treated with splenocytes without activation. All groups were sacrificed to evaluate the tumor profile, hematological and biochemical. Results: The results showed that treatment with HD-H led to decrease tumor volume, their cell counts, increase the percentage of the apoptotic cells and arresting the cancer cell cycle. Moreover, treatment with $\mathrm{HD}-\mathrm{H}$ improved the hematological and biochemical parameters on tumor-bearing mice. Conclusion: In conclusion, HD-H has potential in vitro and in vivo antitumor effects against EAC-cells. Further study is recommended to evaluate the potential efficacy of HD-H as a potential anticancer

Keywords: Anticancer, Apoptosis, Cell cycle, Helix desertorum (HD-H), Hemolymph.

\section{ARTICLE INFO}

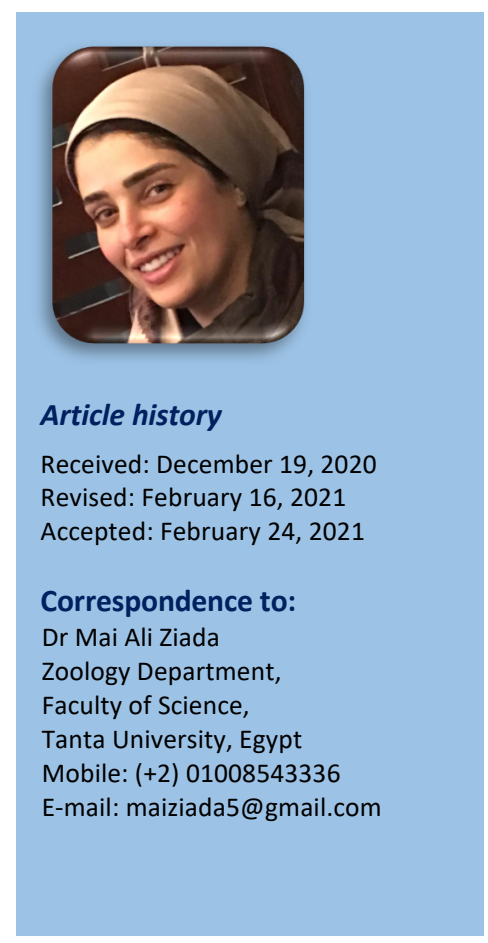

Editor-in-Chief: Prof. M.L. Salem, PhD - Article DOI: 10.21608/JCBR.2021.54156.1105

\section{INTRODUCTION}

Natural products are promising sources for having new anticancer agents. Approximately, half of the currently used anticancer drugs in the markets are derived from natural products due to their chemical diversity (Da Rocha et al., 2001). The terrestrial and marine invertebrates have been less explored to produce safe and novel antitumor compounds (Pomponi, 1999). The chemical and biological diversity of the terrestrial and marine invertebrates are immeasurable and therefore is an extraordinary resource for the discovery of new anticancer drugs (Leng et al., 2005).

In recent years, different marine organisms provided growing interest as potential sources for new anticancer agents against several types of cancers due to their chemical constituents with active antitumor activities (Khalifa et al., 2019; Wali et al., 2019). Till now, thousands of bioactive compounds have been isolated and characterized from marine sources; however, hundreds of new compounds are still being discovered every year (Newman and Cragg, 2004). Currently, several drugs are derived from marine natural products (Schwarzenberg and Vollmar, 2013). Some bioactive compounds extracted from marine sources were isolated, identified, and approved as anticancer drugs (Jimeno et al., 2004). Natural products extracted from terrestrial and marine animals are currently in clinical trials as new drug candidates (Newman and cragg, 2004; Khalifa et al., 2019). This is reflected in the number of marine-derived compounds undergoing preclinical and early clinical development (Schwartsmann et al., 2005). Over the past 
decade, several new experimental anticancer agents derived from marine sources have entered preclinical and clinical evaluations. Thousands of new compounds from marine and terrestrial invertebrates have been described and have entered clinical trials (Cragg et al., 1997). For instance, Cytarabine is considered the first marine-derived anticancer agent be developed for clinical use, which is isolated from a marine sponge that can be used for the treatment of leukemia and lymphoma (Schwartsmann et al., 2001; Hansen and Andersen, 2016).

Hemolymph is the body fluid found in snails; mainly composed of plasma, which is a protein in nature. This hemolymph not only provides nutrients and metabolites but also plays a key role in the response of snails to invading organisms (Martin et al., 2007).Multitudes of proteins whose concentrations change in hemolymph have been identified. For instance, lectins, selectin, galectin, C-type lectin, and fibrinogen-related proteins (FREPs), which are considered to play a promising role in pathogen recognition mechanisms (Vergote et al., 2005; Prasopdee et al., 2015). The present study aimed to address the impact of snails' hemolymph extracts as an anticancer agent, both in vitro and in vivo approaches. To conduct this aim, Helix desertorum snail's hemolymph was used to investigate its antitumor activity against Ehrlisch ascetic carcinoma (EAC) cell line.

\section{MATERIALS AND METHODS}

\section{Chemicals and reagents}

Crystal violet and trypan blue dyes were purchased from Sigma (St. Louis, Mo., USA). Phosphate buffer saline (PBS) was obtained from (Verviers, Belgium). RPMI-1640 media were purchased from Biochrom (Berlin, Germany). L-glutamine, gentamycin and trypsin-EDTA were purchased from Life Technologies (Paisley, Scotland). Penicillin streptomycin, concanvalin A (Con A) and brefeldin A were purchased from Sigma (Sigma Chemical Co., Munich, Germany). Interleukin-2 (IL-2) was obtained from R\&D Systems (Minneapolis, Minnesota, USA). Phosphate buffer saline (PBS) was obtained from (Verviers, Belgium). FACS (fluorescence-activated cell sorting) was purchased from (BD Biosciences, San Jose, CA, USA). Sheath fluid was purchased from (Luminex Crop, Austin, TX, USA) and cisplatin (Cis-diammine dichloro platinumII) purchased from Sigma-Aldrich (St Quentin Fallavier, France). The FITC Annexin V apoptosis (Apoptosis Detection Kit II; Cat. No 556570; BD Bioscience, USA).

\section{Snails}

Helix desertorum snails were collected from their desert habitats. Live snails used in the present experiments were collected during the period from December-January 2018 from ElAlamen, Western desert, Egypt. Snails with the initial body weight of 11-15 g, were kept in the plastic box with dimensions $(50 \mathrm{~cm} \times 50 \mathrm{~cm}$ $x 25 \mathrm{~cm}$ ) and containing the ventilation openings, under proper zoohygienic conditions. Every other day, the box was washed, and a fresh standard diet was provided. Snails were fed two or three times weekly with cabbage leaves. Some collected snails were used for description and identification, while others were used for further studies.

\section{Hemolymph collection}

Hemolymph was collected from each snail (about $1.0 \mathrm{ml}$ per sample) with a 22gaugehypodermic needle from the posterior adductor muscle sinus as described by Auffr et and Oubella (1995), then centrifuged immediately at $800 \mathrm{~g}$ in a cooling centrifuge for 15 minutes at $4{ }^{\circ} \mathrm{C}$ to remove all debris. Supernatant which refers as clean hemolymph was extensively dialyzed against invertebrate isotonic $(50 \mathrm{~m} \mu$ Tris-buffer saline $(\mathrm{pH}$ 8.5) before immediate use or storage at $-80^{\circ} \mathrm{C}$ (Oubella et al., 1996).

\section{In-vitro antitumor assessment of snail'shemolymph:}

Ehrlich Ascities Carcinoma (EAC) cell line was used to assess the in vitro antitumor activity of the hemolymph isolated from Helix desertorum. This tumor grows aggressively as ascites if injected intraperitoneal (i.p). The EAC cell line was purchased from The National Cancer Institute, Cairo University, Egypt. Cell line maintenance: The cell line was maintained by serial transplantation (i.p.) at $2.5 \times 10^{6}$ viable tumor cells in $0.3 \mathrm{ml}$ of saline. EAC cell line was 
cultured according to the standard protocol of cell culture. Cells were cultured in a 6-well plate in RPMI-1640 medium with L-glutamine and supplemented with $10 \%$ fetal bovine serum (FBS) and $1 \%$ of the penicillin-streptomycin solution. Cells were seeded with a density of ( $1 \times 10^{6}$ cells/well), and maintained at $37^{\circ} \mathrm{C}$ in $5 \%$ $\mathrm{CO}_{2} / 95 \%$ air atmosphere, with $95 \%$ humidity in $\mathrm{CO}_{2}$ incubator.

Briefly, cells were cultured in 6-well plate in RPMI-1640 medium with L-glutamine and supplemented with $10 \%$ fetal bovine serum (FBS) and $1 \%$ penicillin-streptomycin solution. Cells were seeded with a density of $\left(1 \times 10^{6}\right.$ cells/well) and maintained at $37{ }^{\circ} \mathrm{C}$ in $5 \%$ CO2atmosphericair, with $95 \%$ humidity in $\mathrm{CO}_{2}$ incubator. Sets of subconfluently plates were treated with different concentrations of hemolymph. Cells were let to grow at $37^{\circ} \mathrm{C}$ in $\mathrm{CO}_{2}$ incubator. After $48 \mathrm{~h}$, cells were harvested by trypsinization using trypsin-EDTA, where old media was decanted, cells were washed with sterile saline $(0.9 \%)$ and $0.5-1 \mathrm{ml}$ of trypsinEDTA solution was added to the cell monolayer. After incubation for 3-5 min, cells were collected for counting or other investigations and these procedures were repeated at $72 \mathrm{~h}$.

In vivo antitumor assessment of adoptively transferred Helix desertorum hemolymph (HDH) stimulated splenocytes

\section{Mice and Ehrlich ascites carcinoma (EAC) tumor cells inoculation}

Female Swiss albino mice (20 \pm 2 g) were obtained from National Research Center (NRC, Cairo, Egypt). Animals were housed in cages (6/cage), in $12 \mathrm{~h} / 12 \mathrm{~h}$ dark/light cycle under laboratory conditions of temperature and humidity. Mice were kept for a week before starting the experiment for acclimatization. Handling of mice was according to the ethical guidelines approved by the animal care and use committee, Faculty of Science, Tanta University (ACUC-SCI-TU), Egypt. The EAC cells were collected from the tumor-bearing mice purchased from the National Cancer Institute ( $\mathrm{NCl}$, Cairo, Egypt). The viable and dead cells were counted using the trypan blue method (The chamber of hemocytometer and a cover slip was cleaned with $70 \%$ alcohol and distilled water. A volume of $10 \mu \mathrm{l}$ of EAC suspension was added to $90 \mu \mathrm{l}$ of trypan blue (Sigma Chemical Co. USA) (0.4\% in distilled water), mixed well and left for 3 minutes. $10 \mu$ l of the mixture was pipetted into the hemocytometer chambers. The cells were counted under a microscope using trypan blue, in all four outer quadrants of the hemocytometer and the number of cells was divided by four to get the cells in one quadrant. The number of EAC/ $(\mathrm{N}) \mathrm{ml}$ was calculated as follows: number of EAC / (N) $\mathrm{ml}=$ cells in one quadrant $\mathrm{x}$ dilution factor $\mathrm{x}$ $10000 \times \mathrm{N}$ (number of $\mathrm{ml}(\mathrm{s})$ of the suspension), tumor cells were adjusted at $1 \times 10^{6}$ cells/mouse for (i.p) inoculation.

\section{Experimental design}

$\left(15 \times 10^{6} / 15 \mathrm{ml}\right)$ cells of splenocytes were cultured using complete RPMI 1640 supplemented with $2 \%$ human serum FPS, 2 $\mathrm{mM}$ L-glutamine, 50 unit $/ \mathrm{ml}$ penicillin, and 50 $\mathrm{ng} / \mathrm{ml}$ streptomycin in the presence of $5 \mu \mathrm{g} / \mathrm{ml}$ concanavalin A (Con A) and 50ng/ml interleukin2 (IL-2) in 3 different flasks then $100 \mu \mathrm{g} / \mathrm{ml}$ of $\mathrm{HD}-\mathrm{H}$ was added to the flasks. Then cultured cells were incubated at $\mathrm{CO} 2$ incubator at $37^{\circ} \mathrm{C}$ in atmospheric pressure of $5 \% \mathrm{CO}_{2}$ for $72 \mathrm{hrs}$. Brefeldin A was added to the cultured cells 3 hours before harvesting.

After harvesting in previously inoculated 40 female Swiss albino mice i.p with 1×10^6 EAC cells/mouse and divided into 5 groups $(n=8)$ as following:

- Group 1 (EAC group): Negative control mice were injected i.p with 1 x106 EAC cells at day 0.

- Group 2 (EAC/Cis): Mice were injected with EAC-cells as in Gp1 and at day 2 were injected with cisplatin $(4 \mathrm{mg} / \mathrm{Kg})$ i.p as a reference drug (positive control).

- Group 3(EAC/Cis/activated spleenocytes with $\mathrm{HD}-\mathrm{H})$ : inoculated with EAC and Cisplatin as in group 2 and then treated with $100 \mu \mathrm{g} / \mathrm{Kg} \mathrm{HD}-\mathrm{H}$ at day 3.

- Group 4 (EAC/Cis/activated spleenocytes): inoculated with EAC and Cisplatin as in group 2 and then treated with activated splenocytes. 
- Group 5 (EAC/Cis/fresh splenocytes): inoculated with EAC and Cisplatin as in group 2 and then treated with fresh splenocytes.

At day 10 , all mice were bled via the orbital plexus to collect blood and sera for hematological and biochemical assessments.

\section{TIMELINE}

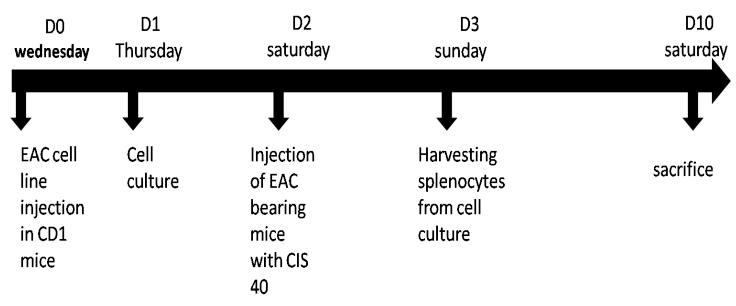

Figure 1. Timeline sketch showing EAC cell line injection and treatment protocol in mice groups.

\section{Counting of tumor cells and splenocytes}

To count the tumor cells, EAC cells suspension was collected and diluted with PBS, and $10 \mu \mathrm{l}$ was added to $90 \mu \mathrm{l}$ of trypan blue. Then $10 \mu \mathrm{l}$ of the mixture was pipetted into the hemocytometer chambers. The cells were counted under a microscope using trypan blue; the number of EAC/ $(\mathrm{N}) \mathrm{ml}$ was calculated as follows:

- NO of EAC / (N) ml=cells in one quadrant $x$ dilution factor $x 10000 \times \mathrm{N}$ (number of $\mathrm{ml}(\mathrm{s})$ of the suspension).

- To count splenocytes, the spleen was collected and placed into Petri dish and crashed gently by glass slides. Splenocytes were filtered and washed twice with PBS, then by ACK buffer and adjusted for the count.

\section{Statistical analysis}

Data were presented as means \pm SD and were analyzed using one-way analysis of variance (ANOVA) followed by Dunnet test at $p<0.05$ (statistically significant).

\section{RESULTS}

In vitro effect of Helix desertorum hemolymph on EAC proliferation capacity post $48 \mathrm{~h}$ treatment

The results as compared to EAC-cells with no treatment showed that all conditions of EACcells, which treated with $\mathrm{Cis}$ alone or with different concentrations of HD-H after 48 hours showed a low rate of proliferation. The effect of different concentrations of HD-H after 48 hours was close to the effect of treatment with 40 or $20 \mu \mathrm{g} / \mathrm{ml}$ of Cis at the same time points (Figure 2).

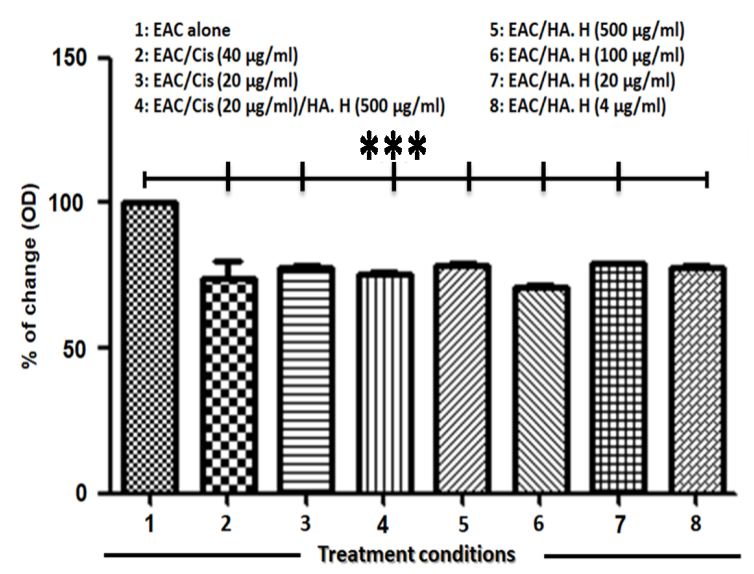

Figure 2. The cytotoxic effect of Helix desertorum (HD-H) hemolymph on EAC-cells 48 hours post-treatment in vitro. $* * *$ refers to significant differences from the control (group1) when $\mathrm{P}<0.001$.

In vitro apoptotic activity of Helix desertorum hemolymph on EAC-cells upon 48 hours treatment

As compared to the untreated EAC-cells, cells that were treated with Cis ( 40 or $20 \mu \mathrm{g} / \mathrm{ml}$ ) post 48 hours showed a significant increase in the percentage of apoptotic cells. Also, EAC-cells that were treated with Cis $(20 \mu \mathrm{g} / \mathrm{ml}) / \mathrm{Helix}$ desertorum hemolymph $(500 \mu \mathrm{g} / \mathrm{ml})$ showed an increase in the percentage of apoptotic EACcells when compared to the untreated cells post 48 hours. Interestingly, the percentage of apoptotic cells post-treatment with Cis (20 $\mu \mathrm{g} / \mathrm{ml}) / H$. desertorum hemolymph $(500 \mu \mathrm{g} / \mathrm{ml})$ or $H$. desertorum hemolymph $(100 \mu \mathrm{g} / \mathrm{ml})$ was higher than the apoptotic percentage of cells post Cis 40 or $20 \mu \mathrm{g} / \mathrm{ml}$ post 48 of the treatment (Figure 3). 


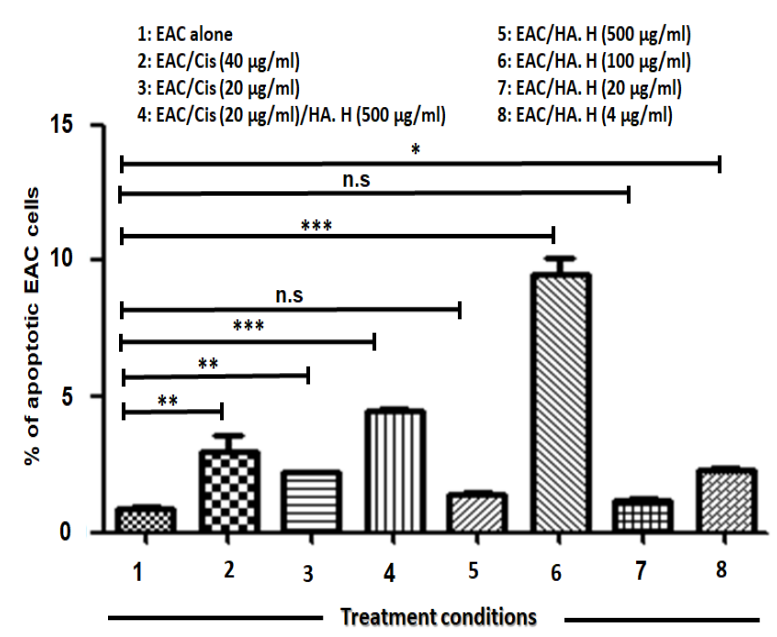

Figure 3. The percentages of apoptotic EAC cells posttreatment with Helix desertorum hemolymph for 48. n.s. refers to non-significant difference between the treatment and the control when $\mathrm{P} \geq 0.001 .{ }^{*},{ }^{* *} \&^{* * *}$ refers to significant differences from the control (group1) when $P$ $<0.05,0.01$ and 0.001 , respectively.

\section{The in vitro effect of Helix desertorum hemolymph on EAC-cell cycle post 48 hours treatment}

The results showed that the percentage of G0/G1 phase increased post 48 hours treatment with Cis $(20 \mu \mathrm{g} / \mathrm{ml}) /$ Helix desertorum hemolymph $(500 \mu \mathrm{g} / \mathrm{ml})$ and Helix desertorum hemolymph alone $(100 \mu \mathrm{g} / \mathrm{ml})$, when compared with non-treated EAC-cells. Consistent with the increase in G0/G1 phase post-treatment with Cis $(20 \mu \mathrm{g} / \mathrm{ml}) /$ Helix desertorum hemolymph $(500 \mu \mathrm{g} / \mathrm{ml})$ and Helix desertorum hemolymph $(100 \mu \mathrm{g} / \mathrm{ml})$ alone, the percentages of S-phase were decreased when compared to non-treated EAC-cells (Figure $4 \mathrm{~A}$ and B). Treatment with Helix desertorum hemolymph $(100 \mu \mathrm{g} / \mathrm{ml})$ alone showed a significant increase in the percentages of $\mathrm{G} 2 / \mathrm{M}$ cell cycle phases when compared to those percentages of untreated EAC-cells post 48 hours of the treatments. Treatment with 40 or $20 \mu \mathrm{g} / \mathrm{ml}$ of Cis for 48 hours did not show any significant changes in the percentages of $\mathrm{G} 2 / \mathrm{M}$, when compared to the non-treated EAC-cells (Figure 4C).
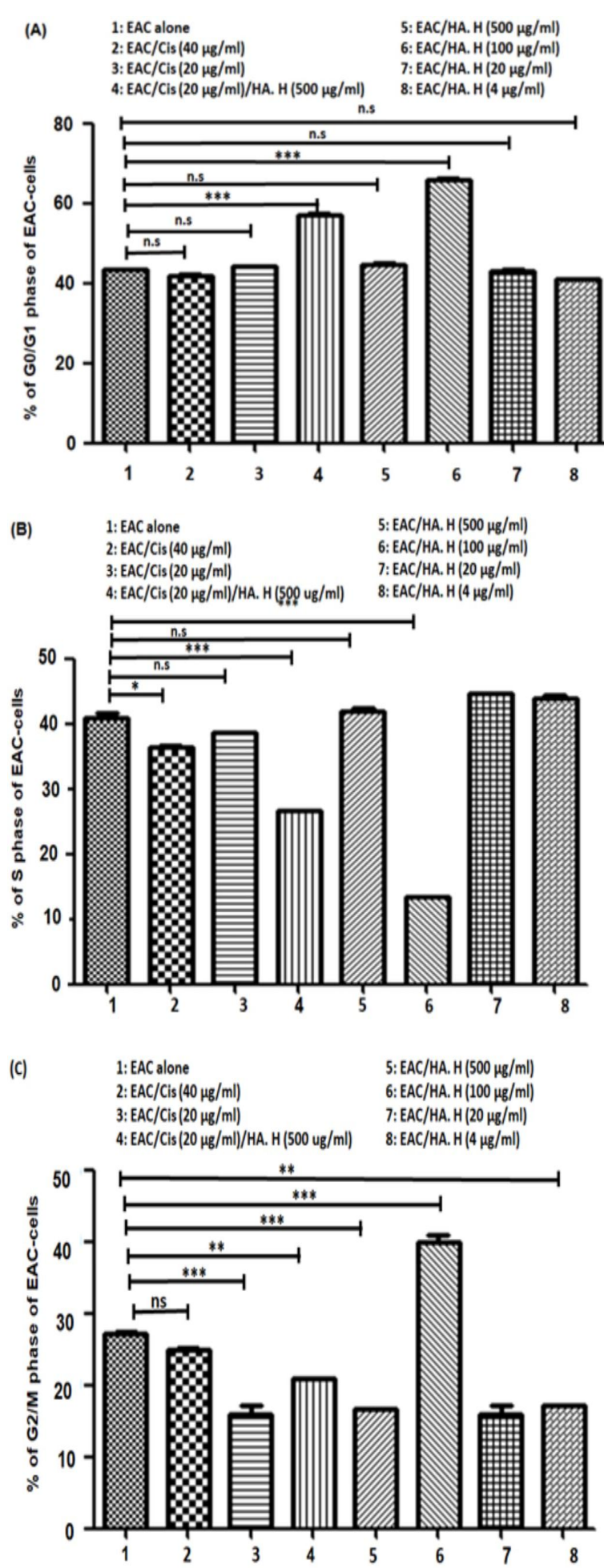

Figure 4 (A-C). Percentages of EAC-cell cycle phases after treatment with Helix desertorum hemolymph (HD-H): (A) G0/G1 phases; (B) S phases and (C) G2/M phases for 48 hours. n.s. refers to non-significant difference between the treatment and the control when $\mathrm{P} \geq 0.001{ }^{*}, * * \& * * *$ refers to significant differences from the control (group1) when $\mathrm{P}<0.05,0.01$ and 0.001 , respectively. 
Effect of adoptively transferred Helix desertorum hemolymph (HD-H) stimulated splenocytes on both EAC-cells and splenocytes count in EAC-bearing mice

As compared to EAC-bearing mice alone, 10 days post $\mathrm{Cis}(40 \mathrm{mg})$ injection, treatment with preconditioned splenocytes in vitro $\mathrm{HD}-\mathrm{H}, \mathrm{II}-$ 2/Con-A alone or with non-activated splenocytes led to a significant decrease in EACcells count (Figure5 A). All treated groups of mice showed a significant increase in splenocytes count followed by the EAC-bearing mice treated with Cis $(40 \mathrm{mg}$ ) when compared to EAC-bearing mice alone (Figure $5 \mathrm{~B}$ ).

(A)

(B)
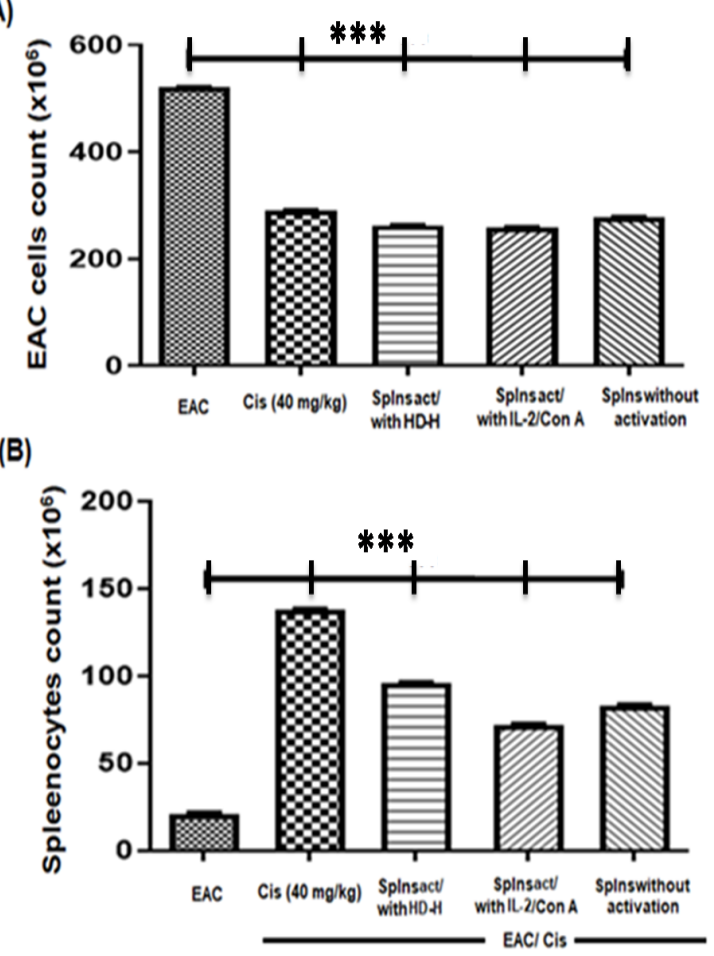

Figure 5 ( $A$ and $B$ ). The count of EAC-cells (A) and splenocytes $(B)$ in groups of EAC-bearing mice treated with splenocytes activated with $\mathrm{HD}-\mathrm{H} .{ }^{* * *}$ refers to significant differences from the control (group1) when $\mathrm{P}<0.001$.

Early, late apoptotic cells percentages and necrotic EAC-cells upon the treatments with the adoptively transferred Helix desertorum hemolymph (HD-H) stimulated splenocytes in EAC-bearing mice

The results showed that post 10 days of Cis ( 40 $\mathrm{mg}$ ) injection, different treatments protocols of Cis/splenocytes activated with HD-H, $\mathrm{Cis} /$ splenocytes activated with IL-2 and Con-A or Cis/splenocytes without activation led to a significant increase in the percentage of apoptotic cells compared to the group of mice which inoculated with EAC-cells (Figure 6A). As compared to the EAC-bearing mice, treatment with Cis $(40 \mathrm{mg}$ ) injection, treatment with $\mathrm{Cis} /$ preconditioned splenocytes/n vitro HD-H, II2/Con-A alone or Cis/ non-activated splenocytes led to a significant increase in the number of early apoptotic cells when compared to mice group which inoculated with EAC-cells alone (Figure 6B). All treated groups showed an increase in the percentages of late apoptotic cells compared to the group of mice inoculated with EAC-cells alone (Figure 7A). As compared to the mice inoculated with EAC-cells, groups of mice treated with $\operatorname{Cis}(40 \mathrm{mg})$, Cis/preconditioned splenocytes In vitro with $\mathrm{HD}-\mathrm{H}$, or treated with Cis/non-activated splenocytes showed a significant decrease in the number of necrotic cells. However, treatment with $\mathrm{Cis} /$ splenocytes activated with IL-2 and Con-A cause a significant increase in the number of necrotic cells as compared with the control group (Figure 7B).

(A)

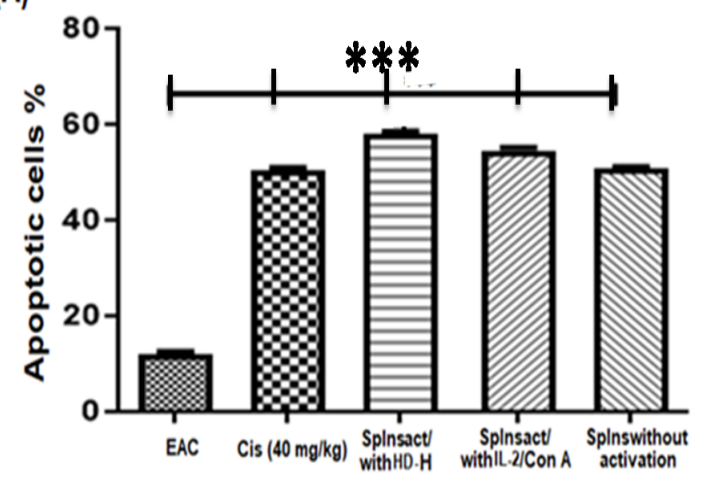

(B)

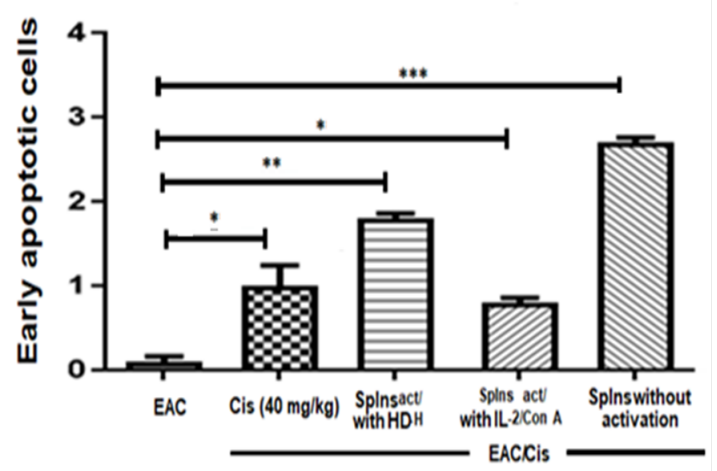

Figure 6 (A and B). Apoptotic cells percentages (A) and early apoptotic EAC-cells (B) in EAC-bearing mice treated with splenocytes activated with $\mathrm{HD}-\mathrm{H} .{ }^{*},{ }^{* *} \&{ }^{* * *}$ refer to significant difference from the control (group1) when $\mathrm{P}<$ $0.05,0.01$ and 0.001 , respectively. 

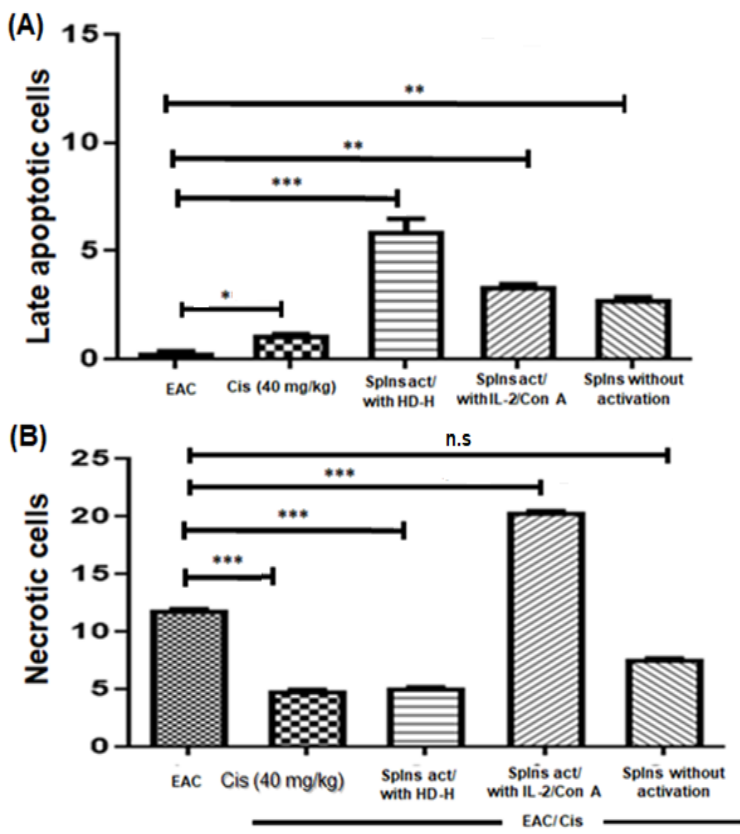

Figure 7 ( $A$ and $B$ ). Late apoptotic EAC-cells (A) and necrotic cells (B) in EAC-bearing mice treated with splenocytes activated with HD-H. n.s. refers to non-significant difference between the treatment and the control when $\mathrm{P}$ $\geq 0.001 .{ }^{*}, * * \& * * *$ refers to significant differences from the control (group1) when $P<0.05,0.01$ and 0.001 , respectively.

EAC-cell cycle G0/G1, $S$ and G2/M phases percentages upon the treatments with adoptively transferred Helix desertorum hemolymph (HD-H) stimulated splenocytes in EAC-bearing mice

The data of EAC-cells cycle analysis showed that Cis (40 mg) injection, different treatments conditions of $\mathrm{Cis} / \mathrm{splenocytes}$ activated with $\mathrm{HD}-\mathrm{H}, \mathrm{Cis} / \mathrm{splenocytes}$ activated with IL-2 and Con-A or Cis/splenocytes without activation after 10 days of EAC-cells inoculation led to a significant decrease in the percentage of G0/G1 phase compared to the group of mice, which inoculated with EAC-cells. A similar pattern was obtained in the data of S-phase percentages (Figure $8 \mathrm{~A}$ and $\mathrm{B}$ ). As compared to the mice inoculated with EAC-cells, groups of mice treated with Cis $(40 \mathrm{mg})$, Cis/preconditioned splenocytes/n vitro with HD-H or treated with Cis/non-activated splenocytes showed a significant decrease in the percentage of $\mathrm{G} 2 / \mathrm{M}$ phase. However, treatment with $\mathrm{Cis} /$ nonactivated splenocytes led to a non-significant decrease in the percentage of $\mathrm{G} 2 / \mathrm{M}$ phase (Figure 9).
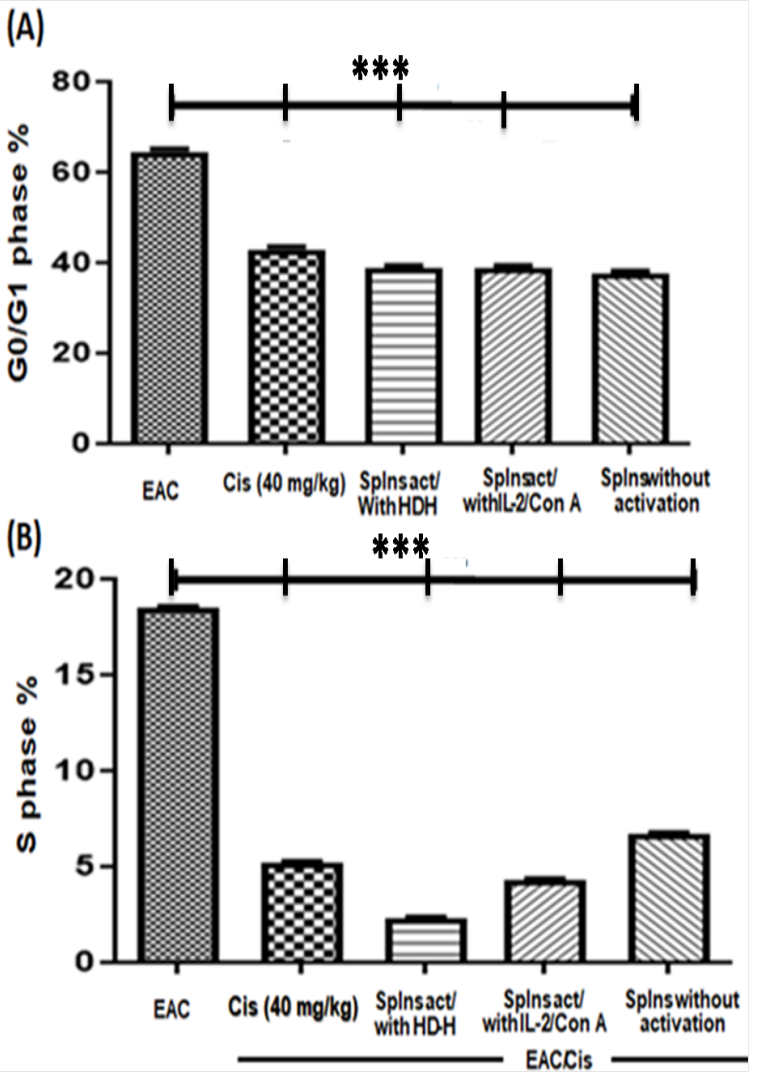

Figure 8 ( $A$ and $B)$. Shows the percentages of EAC-cells cycle phases (A) GO/G1 phase and (B) $S$ phase in EACbearing mice treated with splenocytes activated with HD$\mathrm{H} .{ }^{* * *}$ refers to significant differences between the treatments and the control (group1) when $\mathrm{P}<0.001$.

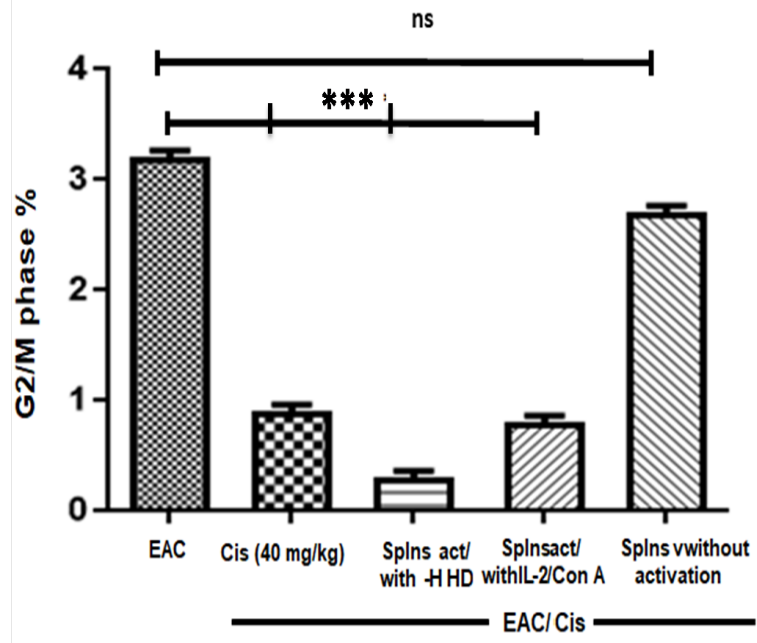

Figure 9. The percentages of EAC-cellsG2/M phase in EACbearing mice treated with splenocytes activated with HD$H$. n.s. refers to the non-significant difference between the treatment and the control when $\mathrm{P} \geq 0.001$. ${ }^{* * *}$ refers to significant differences from the control (group1) when $\mathrm{P}<$ 0.001 . 


\section{DISCUSSION}

Finding new natural products as new chemotherapeutic agents are well recognized nowadays and profound development has been achieved by researchers to deal with different molecular pathways of tumors.

Anticancer compounds have characteristics of multi-function, high sensitivity, and stability (Leng et al., 2005). The hemolymph of the land snail, Helix lucorum and the marine snail Rapanavenosa exhibited potential anticancer activities against human bladder carcinoma cells (T-24) (Dolashka et al., 2015). Furthermore, tissue extracts of some garden snails including Helix aspersa and Actinia equina were shown to possess anticancer activity against breast cancer cells leukemia-derived cells (Teerasak et al., 2016; El Ouar et al., 2017). Isolated hemocyanins from the terrestrial snail Helix pomatia and the marine snail Rapanathomasiana showed promising antiproliferative effects on colon carcinoma (Gesheva et al., 2014).

The results of this study showed that the cytotoxic effect ofdifferent concentrations of $\mathrm{HD}-\mathrm{H}$ on EAC in vitro, 48 hours post-treatment did not show any significant changes when compared to their control. Our data werein agreement with the previous studies that showed the antitumor effects of Helix aspersa hemolymph against bladder cancer (CAL-29), ovarian cancer (FraWü), acute monocytic leukemia (THP-1), prostate cancer (DU-145), glioma cancer (LN-18), and Burkitt's lymphoma (Patra and Muthuraman, 2013; Matusiewicz et al., 2018). Treatment with Cis $(40 \mathrm{mg} / \mathrm{Kg}$ ) postEAC-cells inoculation led to a significant decrease in the number of tumor cells when compared to EAC-group. Also, treatment with $\mathrm{HD}-\mathrm{H}(100 \mu \mathrm{g} / \mathrm{Kg})$ post-EAC-cells inoculation led to a decrease in the tumor cells count, but not that much as Cis treated group. Compared to tumor-bearing mice alone, treatment with Cis (40 $\mathrm{mg} / \mathrm{Kg}$ ) injection, HD-H post-EAC-cells inoculation increased the number of splenocytes significantly, and the number of splenocytes in EAC-bearing mice treated with Cis $(40 \mathrm{mg} / \mathrm{Kg})$ was higher than this number in mice bearing tumor and treated with HD-H (100 $\mu \mathrm{g} / \mathrm{Kg}$ ). The present data werein agreement with the previous studies, which demonstrated increased splenocytes count in tumor-bearing mice treated with chemotherapeutic agents (Merritt et al., 2003; Park et al., 2009; Rosa et al., 2013; Zhu et al., 2019; Hashem et al., 2020).

Apoptosis is a vital homeostatic mechanism to equilibrate the cell division and death, and as a consequence, it is employed by the host to sustain the proper number of cells in the tissue. Apoptotic induction of tumors is a common phenomenon by anticancer treatment and has been recognized as an effective strategy for the development of an anticancer drug. The results of the current study showed that the number of EAC-apoptotic cells post-treatment with Cis (40 $\mathrm{mg} / \mathrm{Kg}$ ) was higher than those of mice inoculated with EAC-cells alone. Treatment with $\mathrm{HD}-\mathrm{H}(100 \mu \mathrm{g} / \mathrm{Kg})$ post EAC inoculation showed an increase in the number of apoptotic cells. As compared to EAC-bearing mice, treatment with Cis or HD-H post tumor inoculation increased the percentages of early apoptotic EAC-cells. Treated groups with $\mathrm{Cis}, \mathrm{HD}-\mathrm{H}$ or $\mathrm{SH}-\mathrm{H}$ showed an increase in the percentages of the late apoptotic EAC-cells, however, the percentage of these cells was higher in HD-H $(100 \mu \mathrm{g} / \mathrm{Kg})$ than those in the group of mice inoculated with EACcells and treated with $\mathrm{Cis}(40 \mathrm{mg} / \mathrm{Kg})$. Our results were in consistent with previous studies that investigated the number of apoptotic cells in tumor-bearing mice treated with chemotherapeutic agents (Zhivotovsky et al., 2006; Donaghy et al., 2010; Patra and Muthuraman, 2013; Matusiewicz et al., 2018; Zhu et al., 2019; Hashem et al., 2020).

Upon the treatment of EAC-bearing mice with Cis $(40 \mathrm{mg} / \mathrm{Kg})$, the percentages of $\mathrm{G} 0 / \mathrm{G} 1$ phase of the EAC-cell cycle were decreased while treatment with HD-H $(100 \mu \mathrm{g} / \mathrm{Kg})$ did not show significant changes in the percentages of this phase compared to EAC-bearing mice alone. Treatment of EAC-mice with Cis alone or with $\mathrm{HD}-\mathrm{H} \quad(100 \mu \mathrm{g} / \mathrm{Kg})$ post-EAC-inoculation decreased the percentages of $S$ phase of the EAC-cells. A similar pattern was found in the $\mathrm{G} 2 / \mathrm{M}$ phase as in the $\mathrm{S}$ phase post-treatment with $\mathrm{Cis}(40 \mathrm{mg} / \mathrm{Kg}), \mathrm{HD}-\mathrm{H}(100 \mu \mathrm{g} / \mathrm{Kg})$. These findings were in consistent with previous studies that investigated the analysis of tumor cell cycle upon treatment with chemotherapeutic agents (Simmons et al., 
2005; Sala-Vila et al., 2010; Donaghy et al., 2010; Rosa et al., 2013; Zhu et al., 2019; Hashem et al., 2020).

\section{CONCLUSION}

In conclusion, hemolymph of Helix desertorum (HD-H) hasa potential antitumor effect against EAC-cells in vivo. Further study is recommended to evaluate the potential efficacy of the hemolymph of HD-H as potential anticancer agents on other tumor models.

\section{CONFLICT OF INTEREST}

Authors declare that they have no conflicts of interest.

\section{FUDING}

There is no financial support for this study.

\section{REFERENCES}

Auffret M, Oubella R. (1995). Cytology and cytometric analysis of bivalve molluschemocytes.(2nd Ed.) J.S. Stolen, (Eds.), Techniques in Fish Immunology, SOS Publications, Fair Haven. 5564.

Blunt JW, Copp BR, Keyzers RA, Munroa MHG, Prinsep MR. (2015). Marine natural products. Natural Product Reports 32: 116.

Cragg GM, Newman DJ, Weiss RB. (1997). Coral reefs, forests, and thermal vents: The worldwide exploration of nature for novel antitumor agents. Seminars in Oncology. 24: 156-163.

Da Rocha AB, Lopes RM, Schwartsmann G. (2001). Natural products in anticancer therapy.Current Opinion in Pharmacology. 1: 364-369.

Dolashka P, Dolashki A, Velkova L, Stevanovic S, Molin L, Traldi P, Velikova R, Voelter W. (2015). Bioactive compounds isolated from garden snails. Journal of BioScience and Biotechnology. SE: 147-155.

Donaghy L, Hong H, Lambert C, Park H, Shim WJ, Choi K. (2010). First characterisation of the populations and immune-related activities of hemocytes from two edible gastropod species, the disk abalone, Haliotis discus and the spiny top shell, Turbo cornutus. Fish and Shellfish Immunology, 28 (1): 87-97.

El Ouar I, Braicu C, Naimi D, Irimie A, BerindanNeagoe I. (2017). Effect of Helix aspersa extract on TNF $\alpha, N F-k B$ and some tumor suppressor genes in breast cancer cell line Hs578T. Pharmacognosy Magazine. 13: 281-285.

Gesheva V, Chausheva S, Mihaylova N, Manoylov I,
Doumanova L, Idakieva K, Tchorbanov A. (2014). Anti-cancer properties of gastropodanhemocyanins in murine model of colon carcinoma.BMC Immunology. 15: 34.

Hansen E, Andersen JH. (2016). Screening for Marine Natural Products with Potential as Chemotherapeutics for Acute Myeloid Leukemia. Current Pharmaceutical Biotechnology. 17(1): 71-77.

Hansen E, Andersen JH. (2016). Screening for Marine Natural Products with Potential as Chemotherapeutics for Acute Myeloid Leukemia. Current Pharmaceutical Biotechnology. 17(1): 71-77.

Hashem MA, Mahmoud EA, Abd-Allah NA.(2020). Alterations in hematological and biochemical parameters and DNA status in mice bearing Ehrlich ascites carcinoma cells and treated with cisplatin and cyclophosphamide.Comparative Clinical Pathology. 29: 517-524

Jimeno J, Lopez-Martin JA, Ruiz-Casado A, Izquierdo MA, Scheuer PJ, Rinehart K. (2004). Progress in the clinical development of new marinederived anticancer compounds, Anticancer Drugs 15: 321-329.

Karikas GA. (2010). Anticancer and chemopreventing natural products: some biochemical and therapeutic aspects. Journal of the Balkan Union of Oncology 15(4): 627-638.

Khalifa SAM, Elias N, Farag MA, Chen L, Saeed A, Hegazy MF, Moustafa MS, El-Wahed AA, AlMousawi SM, Musharraf SG, Chang F, Iwasaki A, Suenaga K, Alajlani M, Göransson U, El-Seedi HR. (2019). Marine natural products: a source of novel anticancer drugs. Marine Drugs.17, 491.

Le Tourneau C, Faivre S, Ciruelos E, Dominguez MJ, Lopez-Martin JA, Izquierdo MA, Jimeno J, Raymond E. (2010). Reports of clinical benefit of plitidepsin (Aplidine), a new marine-derived anticancer agent, in patients with advanced medullary thyroid carcinoma. American Journal of Clinical Oncology. 33(2): 132-136.

Leng B, Liu XD, Chen QX. (2005). Inhibitory effects of anticancer peptide from Mercenaria on the BGC-823 cells and several enzymes.FEBS Letters. 579: 1187-1190.

Martin GG, Oakes CT, Tousignant HR, Crabtree H, Yamakawa R. (2007). Structure and function of haemocytes in two marine gastropods, Megathuracrenulata and Aplysiacalifornica. Journal of Molluscan Studies. 73 (4):355-65.

Matusiewicz M, Kosieradzka I, Niemiec T, Grodzik M, Antushevich H, Strojny B, Gołębiewska M. (2018). In vitro influence of extracts from snail helix aspersamüller on the colon 
cancer cell line Caco-2. International journal of molecular sciences. 19(4): 1064.

Merritt RE, Mahtabifard A, Yamada RE, Crystal RG, Korst RJ. (2003). Cisplatin augments cytotoxic tlymphocyte-mediated antitumor immunity in poorly immunogenic murine lung cancer. The Journal of Thoracic and Cardiovascular Surgery126(5): 1609-1617.

Newman DJ, Cragg GM. (2004). Marine natural products and related compounds in clinical and advanced preclinical trials, Journal of Natural Products 67: 1216-1238.

Oubella R, Maes P, Allam B, Paillard C, Auffret M. (1996). Selective induction of hemocytic response in Ruditapesphilippinarum (Bivalvia) by different species of Vibrio (Bacteria).AquatLiving Resources. 9: 137-143.

Park H, Ju E, Jo S, Jung U, Kim S, Yee S. (2009). Enhanced antitumor efficacy of cisplatin in combination with hemohim in tumor-bearing mice.BMC Cancer. 17: 9:85.

Patra S, Muthuraman MS. (2013). Gracilariaedulis extract induces apoptosis and inhibits tumor in Ehrlich ascites tumor cells in vivo. BMC Complementary and Alternative Medicine. 13: 331.

Prasopdee S, Tesana S, Cantacessi C, Laha T, Mulvenna J, Grams R. (2015). Proteomic profile of Bithynia siamensisgoniomphalos snails upon infection with the carcinogenic liver fluke Opisthorchisviverrini.Journal of Proteomics. 113:281-291.

Rosa A, Scano P, Atzeri A, Deiana M, Falchi AM. (2013). Potential Anti-Tumor Effects of MugilCephalus Processed Roe Extracts on Colon Cancer Cells. Food and Chemical Toxicology. 60: 471-478.

Sala-Vila A, Folkes J, Calde PC. (2010). The effect of three lipid emulsions differing in fatty acid composition on growth, apoptosis and cell cycle arrest in the HT-29 colorectal cancer cell line. Clinical Nutrition. 29: 519-524.

Schwartsmann G, da Rocha AB, Mattei J, Lopes RM. (2005). Marine-derived anticancer agents in clinical trials.Expert Opinion on Investigational Drugs. 12(8): 1367-1383.

Schwartsmann G, Brondani da Rocha A, Berlinck RG, Jimeno J. (2001). Marine organisms as a source of new anticancer agents. The Lancet Oncology. 2(4): 221-225.

Schwarzenberg KV, Vollmar AM. (2013). Targeting apoptosis pathways by natural compounds in cancer: Marine compounds as lead structures and chemical tools for cancer therapy. Cancer Letters 332: 295-303.

Simmons TL, Andrianasolo E, McPhail K, Flatt P, Gerwick WH. (2005). Marine natural products as anticancer drugs.Molecular Cancer Therapeutics. 4(2): 333-342.

Teerasak E, Thongararm P, Roytrakul S, Meesuk L, Chumnanpuen P. (2016). Prediction of anticancer peptides against MCF-7 breast cancer cells from the peptidomes of Achatinafulica mucus fractions. Computational Structural Biotechnology Journal. 14: 49-57.

Vergote D, Bouchut A, Sautiere PE, Roger E, Galinier R, Rognon A. (2005). Characterisation of proteins differentially present in the plasma of Biomphalariaglabrata susceptible or resistant to Echinostomacaproni. International Journal forParasitology. 35(2): 215-24.

Wali AF, Majid S, Rasool S, Shehada SB, Abdulkareem SK, Firdous A, Beigh S, Shakeel S, Mushtaq S, Akbar I, Madhkali H, Rehman MU. (2019). Natural products against cancer: Review on phytochemicals from marine sources in preventing cancer. Saudi Pharmaceutical Journal. 27: 767-777.

Zhivotovsky B, Orrenius S. (2006). Carcinogenesis and apoptosis: paradigms and paradoxes. Carcinogenesis. 27: 1939-1945

Zhu J, Xu J, Jiang L, Huang J, Yan J, Chen Y, Yang Q. (2019). Improved antitumor activity of cisplatin combined with Ganodermalucidum polysaccharides in U14 cervical carcinomabearing mice. Kaohsiung Journal of Medical Science. 35: 222-229. 


\section{Egyptian Association for Cancer Research (EACR)}

http://eacr.tanta.edu.eg/

EACR is an NGO society that was declared by the Ministry of Social Solidarity (Egypt) No. 1938 in 19/11/2014 based on the initiative of Prof. Mohamed Labib Salem, the current Chairman of EACR. EACR aims primarily to assist researchers, in particular young researchers in the field of cancer research through workshops, seminars and conferences. Its first international annual conference entitled "Anti-Cancer Drug Discovery" was successfully organized in April 2019 (http://acdd.tanta.edu.eg). Additionally, EACR aims to raise the awareness of the society about the importance of scientific research in the field of cancer research in prediction, early diagnosis and treatment of cancer. EACR is also keen to outreach the scientific community with periodicals and news on cancer research including peer-reviewed scientific journals for the publication of cutting-edge research. The official scientific journal of EACR is "International Journal of Cancer and biomedical Research (IJCBR: https://jcbr.journals.ekb.eg) was successfully issued in 2017 and has been sponsored by the Egyptian Knowledge Bank (EKB: www.ekb.eg).

\section{EACR Chairman,}

Prof. Mohamed Labib Salem, PhD

Professor of Immunology

Faculty of Science, Tanta Universiy, Egypt 
International Journal of Cancer and Biomedical Research (IJCBR), a publication of the Egyptian Association for Cancer Research (EACR), is a peer-reviewed online journal published quarterly. The journal allows free access (Open Access) to its contents and permits authors to self-archive a final accepted version of the articles on any OAl-compliant institutional / subject-based repository.

\section{Aim And Scope}

Aim: The main aim of IJCBR is to attract the best research in animal and human biology in health and diseases from across the spectrum of the biomedical sciences at the molecular, cellular, organ, and whole animal levels especially those that are related to cancer research, including causes, prediction, diagnosis, prognosis and therapy.

Scope: It is essential reading for all researchers interested in biochemistry, cancer, microbiology, nutrition, physiology, genetics, immunology, epidemiology, medical economics, human biology, bioinformatics, biotechnology, nanotechnology, and disease modeling.

\section{Publication Ethics}

Researchers should conduct their research from research proposal to publication in line with the best practices and codes of conduct of relevant professional bodies and/or national and international regulatory bodies. IJCBR accepts manuscripts prepared in accordance with the "Uniform Requirements for Submission of Manuscripts for Biomedical Journals adopted by the International Committee of Medical Journal Editors (ICMJE) and the Committee on Publication Ethics (COPE). Details of ICMJE and COPE are available at http://www.icmje.org/ and http://publicationethics.org/

\section{Peer Review Process}

After the IJCBR editor receives a manuscript, the first step is to confirm that the manuscript meets the journal's rules for content and format, including similarity check (plagiarism) which should be less than $25 \%$. If the manuscript meets the journal's rules, the editor then assign it to the double-blind peer review process. The IJCBR editor send the manuscript to at least two experts in the field for RIGOROUS scientific evaluation. The experts called peer reviewers - will then prepare a report that assesses the manuscript and return it to the editor through the IJCBR portal. Upon the first submission, this reviewing process takes about 4 to 6 weeks. After reading the peer reviewer's report, the editor will decide one of the following four options:

1. Reject the manuscript.

2. Accept the manuscript

3. Ask the authors to revise and resubmit the manuscript after responding to the peer reviewers' feedback.

4. Ask for peer-review from additional reviewers.

If the authors resubmit the manuscript, the IJCBR editor will ask the same peer-reviewers to look over the manuscript again to confirm that their concerns have been addressed. This is called re-review process. This second revision (if applicable) takes about another 4 to 6 weeks. At this point, the abstract of the article appears in press. The online publication (the PDF format) of the final version of the manuscript takes from 2 to 4 weeks. As such, the total publication cycle takes from 2 to 4 months. This cycle can be reduced to 4 to 6 weeks (fast track publication) for the manuscripts with outstanding findings.

The peer-review process used by IJCBR includes comments on errors in the study's methods or analysis that raise questions about the findings, or sections that need clearer explanations. The peer-review process also includes the importance and novelty of the manuscript and its interest to the journal's audience. The IJCBR uses double-blind review, which means that both the reviewers and authors identities are concealed from the reviewers, and vice versa, throughout the review process. To facilitate this, authors need to submit a Title Page containing the Authors details and Blinded Manuscript with no author details as 2 separate files. 


\section{Publisher}

The International Journal of Cancer and Biomedical Research (IJCBR) is an International and interdisciplinary journal of preclinical and clinical studies in the area of cancer and biomedical research. It is a peer-reviewed journal in English, published quarterly (in March, June, September, and December) by the Egyptian Association for Cancer Research (EACR) in both print and online formats (4 issues making a volume). Special issues or supplements may also be produced from time to time upon agreement with the Editorial Board.

\section{Scope}

The main aim of IJCBR is to attract the best research in animal and human biology in health and diseases from across the spectrum of the biomedical sciences at the molecular, cellular, organ, and whole animal levels especially those that are related to cancer research, including causes, prediction, diagnosis, prognosis and therapy.

\section{Publication Fees}

The journal does charge for submission, processing or publication of manuscripts (2000 LE for Egyptians or $\$ 300$ for non-Egyptians; EACR members receive 15\% discount on publication). Of them Peer-review fees (300 LE) should be paid on submission (non-refundable). For the fast track production of the accepted manuscript, another $500 \mathrm{LE}$ is paid.

General specifications for different types of article

- Submitted manuscripts should not have been published previously, except in a limited form (e.g. short communication to a symposium or as part of MSc or PhD theses) and should not be under consideration for publication by other journals.

- All co-authors should agree with the content of the manuscript. Authors must have obtained permission to use any copyrighted material in the manuscript before submission.

\section{IJCBR publishes different types of articles}

- Original Article (6000 words with $\mathbf{4}$ tables and $\mathbf{4}$ figures, maximum $\mathbf{8}$ display items): Articles with novel findings are the target of IJCBR. Articles presenting a detailed description of a new technique, comparison of existing methods, meta-analyses with comprehensive and in-depth discussion are considered. Papers in a numbered series are not accepted unless all are submitted at the same time.

- Short communications or case study (3000 words with 4 display items): Short communications present exceptionally exciting, novel or timely contents are considered. They will be peer-reviewed in the same way as research papers. The references are restricted to 15 .

- Reviews or systematic review (9000 words with $\mathbf{1 0}$ display items): They are invited by the Editorial Board or unsolicited. Review articles have to be contemporary and comprehensive and add information to the knowledge. Sharp critical analyses of novel data or concepts are encouraged. When relevant, a statistical analysis of data and a meta-analysis approach are recommended.

- Opinion papers, letter to the editor or comment to the editor (1500 words with $\mathbf{2}$ display items): They are submitted by invitation of the Editorial Board. They are short papers, which aim to inform scientists, industry, and the public and policymakers about cutting-edge issues in research or the impact of research. They reflect the opinion of their authors who bear full responsibility of the published paper. The references are restricted to 10 .

- Conference/Symposium papers: The journal will consider for publication the results of original work and critical reviews that are presented at conferences/symposia. Symposium organizers who wish to publish bundles of papers from a symposium/conference in IJCBR should first contact the Editor-inChief of the IJCBR (EACR@unv.tanta.edu.eg) for agreement. Supplementary material can be proposed and will be made available online. The responsibility for the preparation of a paper in a form suitable for publication lies with the author.

- Thesis: IJCBR can publish the summary and abstract of Master and PhD theses in a special issue. 
English: Good quality of written English is required. Spelling may be in British or American English but must be consistent throughout the paper. Care should be exercised in the use of biological terminology that is ill-defined or of local familiarity only. We recommend that authors have their manuscripts checked by an English language native speaker before submission.

Manuscript layout: Manuscripts should be prepared using a standard word processing program and presented in a clear readable format with easily identified sections and headings. The manuscript layout is based on the following directions.

- The main text contains Title, Abstract, Keywords, Introduction, Material and Methods, Results, Discussion, References, Tables, figures.

- The title needs to be concise and informative. Use bold, with an initial capital for the first word only and for words that ordinarily take capitals

- Short (running) title (max 80 characters including spacing).

- The article text should be typed with double-line spacing with wide margins $(2.5 \mathrm{~cm})$.

- The lines must be continuously numbered; the pages must also be numbered.

- Font Calibri 12 should be used for the text, and 12 for the tables, figure legends and references.

- The sections should typically be assembled in the following order:

- Title page contains title, authors' names, full affiliations, acknowledgements and the corresponding author's contacts and Short title.

Abstract (max 250 words, single paragraph): The abstract should be complete and understandable without citation, references, table or figure. Use structured abstract: Background, Aim, Materials \& Methods, Results and Conclusion. The context and the rationale of the study are presented succinctly to support the objectives. The experimental methods and main results are summarized but should not be overburdened by numerical values or probability values. The abstract ends with a short and clear conclusion.

Keywords: Up to five short and specific keywords should complement the title with respect to indicating the subject of the paper in alphabetic order.

Introduction: The introduction briefly outlines the context of the work, presents the current issues that the authors are addressing and the rationale to support the objectives, and clearly defines the objectives.

Material and methods: Material and methods should be described in sufficient details so that others can repeat the experiment. Reference to previously published work may be used to give methodological details, provided that said publications are readily accessible and in English. The code of ethics should be followed for all experiments use animals or human samples.

Statistical analysis of results: The statistical design and the models of statistical analysis must be described, as well as each of the statistical methods used. Sufficient statistical details must be given to allow replication of the statistical analysis. The experimental unit should be defined (e.g. individual or group of animals).

Results: Data are presented as tables and figures. Brief description of the results for each table and figure should be presented. Unpublished data can be mentioned when necessary.

Discussion: Should be separate from the Results section and should focus only on intra- and inter-data discussion (the data in the results section) as well as with the relative data in the literature. Don't repeat information already presented in the Introduction section. Start the first paragraph in the Discussion with a paragraph stating the rationale behind the study, the objectives and the main findings. End Discussion with a short conclusion.

Acknowledgements: In this section, the authors may acknowledge (briefly) their support staff.

Conflict of interest: All papers with a potential conflict of interest must include a description/explanation in a separate heading.

Funding details: The authors should state the source of findings of the study (with research funder and/or grant number). If no fund, the authors should state that the study is self-funded. 


\section{References}

Citation of references: In the text, references should be cited by the author(s) surname(s) and the year of publication (e.g. Salem, 2020). References with two authors should be cited with both surnames (e.g. Salem and Meshrif, 2021). References with three or more authors should be cited with the first author followed by et al. (in italics; e.g. Salem et al., 2021). Names of organizations used as authors (e.g. Food and Drug Administration) should be written out in full in the list of references and on the first mention in the text. Subsequent mentions may be abbreviated (e.g. FDA).

- List of references. Literature cited should be listed in alphabetical order by authors' names. It is the author's responsibility to ensure that all references are correct. All authors should be written and so the full journal name.

- References from journal articles are formatted in APA as this example: Al-Amoudi WM (2018). Toxic effects of Lambda-cyhalothrin on the rat thyroid. Involvement of oxidative stress and ameliorative effect of ginger extract. Toxicology Reports, 5: 728-736.

- References from books or official reports are formatted as this example. Kebreab E, Dijkstra ANM, Bannink A, Gerrits WJJ, \& France J (2006). Nutrient digestion and utilization in farm animals. CABI Publishing. Wallingford, UK.

- References from chapters or parts of books are formatted as this example. Nozière $P, \&$ Hoch $T$ (2006). Modelling fluxes of volatile fatty acids from rumen to portal blood. In: Nutrient digestion and utilization in farm animals (Kebreab E, Dijkstra ANM, Bannink A, Gerrits WJJ \& France J, eds.), pp. 40-47. CABI Publishing. Wallingford, UK.

Tables:

The data should be presented in tables or in graphs, not both.

- Each table should be placed on a separate page at the end of the main text.

- Tables are numbered consecutively using Arabic numbering. They are referred to as Table 1 , Table 2, etc., with capital ' $T$ ', no italics

- Each table has its explanatory caption. The caption is sufficient to permit the table to be understood without reference to the text.

- Abbreviations used in tables/figures have to be defined either as footnotes or in the caption.

Figures

- Package the figures in a single PowerPoint file. Each figure in a separate slide.

- Figure size should be readable in a width of approximately 8-175 $\mathrm{mm}$ (i.e. the maximum size of printing over two columns).

- Ensure that the font size is large enough to be readable at the final print size, use Calibri font to ensure that they are consistent throughout the figures.

- The figures should preferably be provided as TIFF or EPS files.

- The resolutions of figures must be at least $300 \mathrm{dpi}$.

- Preparation of images for a manuscript: For guidance, we refer to the Journal of Cell Biology's instructions to authors (http://jcb.rupress.org/site/misc/ifora.xhtml\#image_aquisition).

- If a cropped image is included in the main text of a paper (e.g. a few lanes of a gel), display the full original image, including the appropriate controls, the molecular size ladder and/or the scale as relevant, as a single figure in a Supplementary Material file to facilitate peer-review and for subsequent online publication.

- Supplementary material is submitted along with the main manuscript in a separate file and identified at uploading as "Supplementary File - for Online Publication Only" The title of the article is included at the top of the supplementary material.

Corresponding author's guidelines: Upon acceptance the corresponding author is required to send his/her recent formal photo to be attached to the front page of the article. 


\title{
International Journal of Cancer \& Biomedical Research
}

(IJCBR) Online ISSN 2682-2628

\author{
Editor-in-Chief \\ Mohamed Labib Salem, PhD \\ Tanta University, Egypt
}

\begin{tabular}{l} 
EACR Board \\
\hline Nehal Elmashad, MD \\
Tanta University, Egypt \\
Nabil Mohy Eldin, PhD \\
Kafrelsheikh University, Egypt \\
Doaa Al-Ghareeb, PhD \\
Alexandria University, Egypt \\
Abdel-Aziz Zidan, PhD \\
Damanhour University, Egypt
\end{tabular}

\begin{tabular}{l} 
Managing Editor \\
\hline Wesam Meshrif, PhD \\
Tanta University, Egypt \\
Sohaila Galal, PhD \\
Tanta University, Egypt \\
Production and Contact \\
\hline Hamdi Kandil \\
Tanta University, Egypt \\
Email: ljcbr100@gmail.com
\end{tabular}

\section{Advisory Board}

Alberto Montero, MD

Taussig Cancer Center, Cleveland,

USA

Yi Zhang, MD

Zhengzhou University, China

Mark Robunstein, Ph D

Medical University of South

Carolina, USA

Mohsen Farid, Ph D

Derby University, USA

Natarajan Muthusamy, Ph D

Ohio State University, USA

Hideki Kasuya, MD

Nagoya University, Japan

Sherif El-Khamisy, Ph D

Sheffield University, UK

Mohamed Ghanem, Ph D

Kafr Elshikh University, Egypt

Sayed Bakry, Ph D

Alazhar University, Egypt

Sameh Ali, Ph D

Nationa Liver Institute, Egypt

Gamal Badr, Ph D

Assuit University, Egypt

Nadia Hamdy, Pharm D

Ain Shams University, Egypt

\section{Editorial Board}

\section{Clinical studies}

Hesham Tawfik, MD

Tanta University, Egypt

Mohamed Attia, MD

Tanta University, Egypt

Mohamed Elshanshory, MD

Tanta University, Egypt

Essam Elshiekh, MD

Tanta Cancer Center, Egypt

Rasha Eraky, MD

Tanta University, Egypt

Shaima Abou-Kjatwa, MD

Tanta University, Egypt

Marcela Diaz, MD

Cleveland Clinic Foundation, USA

Mohamed Abou-El-Enein, MD

Charité Universitätsmedizin Berlin,

Germany
Alaa Eldin Almostafa, MD

McGill University, Canada

Olfat Gadallah, MD

Tanta University, Egypt

Nagla Sarhan, MD

Tanta University, Egypt

Naglaa Fathy, Pharm D

Zagazik University, Egypt

Mohamed Salama, MD

Mansoura University, Egypt

Mona Marie, MD

Alexandria University, Egypt

Preclinical studies

Mostafa El-Sheekh

Tanta University, Egypt

El-Refai Kenawy, Ph D

Tanta University, Egypt

Mohamed Noureldin, Ph D

Banaha University, Egypt

Yousry Albolkiny, Ph D

Tanta University, Egypt

Elsayed Salim, Ph D

Tanta University, Egypt

Shengdian Wang, Ph D

Chinese Academy of Sciences,

China

Sabry El Naggar, Ph D

Tnata Univesity, Egypr

Faris Alenzi, Ph D

Prince Sattam bin Abdulaziz

University, KSA

Ibrahim El-Sayed, Ph D

Menoufia University, Egypt

Tarek Aboul-Fadl, Ph D

Assiut University, Egypt

Rabab Khairat, Ph D

National Research Center,

Giza, Egypt

Wael Lotfy, Ph D

Alexandria University, Egypt

Ashraf Tabll, Ph D

National Research Center, Egypt

Nahla Shoukry, Ph D

Suez University, Egypt
Medhat Eldenary, Ph D

Tanta University, Egypt

Azza Hasan, Ph D

Menufia University, Egypt

Nanees Gamal Eldin, Ph D

Tanta University, Egypt

Mohamed Mansour, UK

Sabbah Hammoury, Ph D

Alexandria Ayadi Almostaqba

Oncology Hospital, Egypt

Nehal Aboulfotoh, Ph D

Zewail City for Science and

Technology, Cairo, Egypt

Amir Elkhami, Ph D

Galaxo, San Francisco, USA

Ahmed Alzohairy, Ph D

Zagazi University, Egypt

Wgady Khalil, Ph D

National Research Center, Egypt

Amr Amin, Ph D

United Arab Emirates

University, UAE

AbdelRahman Zekri, Ph D

National Cancer Institute, Egypt

Hussein Khamis, Ph D

Alexandria University, Egypt

Magdy Mahfouz, Ph D

Kafr Elsheikh University, Egypt

Ehab Elbedewey, Ph D

Tanta University, Egypt

Abeer Badr, Ph D

Cairo University, Egypt

Mamdooh Ghoneum, Ph D

Charles Drew University of

Medicine \& Science, USA

Haiam Abou Elela, Ph D

National Institute of Oceanography and Fisherie, Egypt

Maha EL-Demellawi, Ph D City for Scientific Research \&

Technology Applications, Egypt

Desouky Abd-El-Haleem, Ph D

City for Scientific Research \&

Technology Applications, Egypt 